\title{
"NÃO QUERO LEMBRAR... MUITO SOFRIMENTO": PERCURSOS DA MEMÓRIA ENTRE OS REFUGIADOS PALESTINOS NO BRASIL
}

\author{
Daniele Regina Abilas Prates* \\ Universidade Federal Fluminense - Brasil
}

Resumo: Durante minha pesquisa etnográfica junto ao grupo de refugiados palestinos reassentados em Mogi das Cruzes (SP), questões relacionadas à memória se fizeram presentes desde o primeiro contato. Em um momento em que os indivíduos buscavam dar início a uma nova vida, falar do que viveram era sempre constrangido com uma forte carga emocional ou com uma tentativa de apagamento. Entre o esquecer e tentar viver uma nova vida e o relatar e fazer com que se entendesse o que eles vivenciaram no passado, estava a dificuldade de lidar com a memória traumática. Embora houvessem vivenciado situações similares, e por longos anos dividissem a mesma realidade no campo de refugiados onde ficaram alojados em abrigos temporários - entre 2003 e 2007, quando foram reassentados no Brasil -, cada um dos refugiados optava por uma dinâmica diferente. Este artigo pretende discutir essas estruturas mediadoras e a relação entre memória traumática e memória do trauma na experiência diária dos refugiados palestinos em Mogi das Cruzes.

Palavras-chave: auxílios da memória, memória do trauma, memória traumática, refúgio.

Abstract: During my ethnographic research with the group of Palestinian refugees
resettled in the Mogi das Cruzes - SP, issues related to memory have made present
from the first contact. At a time in which individuals were seeking to start a new life,
talk about what they had lived was always constraint by a strong emotional charge
or an attempt to erase. Between forgetting and trying to live a new life and to share
and make the others understand what they have experienced in the past, was the dif-
ficulty of dealing with the traumatic memory. Although they had experienced similar
situations and for many years shared the same reality in the refugee camp where they

* Doutoranda em Antropologia, bolsista PSDE/Capes; pesquisadora Neom/UFF com financiamento do CNPq.

Horizontes Antropológicos, Porto Alegre, ano 20, n. 42, p. 133-152, jul./dez. 2014 http://dx.doi.org/10.1590/S0104-71832014000200006 
were hosted in temporary shelters - between 2003 and 2007, when they were resettled in Brazil - each of refugees opted for a different dynamic. This article aims to discuss these mediating structures and the relationship between traumatic memory and memory of trauma in the daily experience of Palestinian refugees in Mogi das Cruzes.

Keywords: memory aids, memory of trauma, refuge, traumatic memory.

\section{Dinâmicas da memória: entre a lembrança e o esquecimentol}

Nos relatos de meus informantes, seria constante a afirmação sobre uma tentativa de romper com o passado na busca de uma reconstrução da vida, como nas palavras de Ibrahim: ${ }^{2}$ "Eu quero esquecer o passado, tudo que aconteceu, só quero pensar no futuro. No campo eu me sentia como um animal, não me sentia uma pessoa. Agora eu voltei a me sentir humano, quero levar uma vida normal." Mas mesmo esse sentimento é ambivalente, pois se congrega a outros sentimentos de rememoração e afirmação da memória histórica - o próprio Ibrahim elaborou manuscritos de suas memórias, em que descreve sua vida no Iraque, os acontecimentos pós-2003, e a vida no campo de refugiados.

Conversar sobre a experiência vivida no campo de refugiados ${ }^{3}$ não seria uma tarefa fácil, embora tenha percebido, nos primeiros contatos que fiz em Mogi das Cruzes (SP), que já esperavam de mim essa pergunta. Talvez por causa do contato que tiveram com outros pesquisadores, ou das constantes idas e vindas de jornalistas, falar do campo parecia obrigatório. Contudo, de maneira geral, as afirmações eram sempre as mesmas, superficiais e objetivas; pareciam dizer o que qualquer pessoa já sabe: "Era muito difícil... tinha muito

\footnotetext{
Este artigo é parte de uma discussão mais ampla traçada em minha dissertação de mestrado em Antropologia no Programa de Pós-Graduação da Universidade Federal Fluminense, defendida em 2012 sob o título $O$ fio de Ariadne: deslocamento, heterotopia e memória entre os refugiados palestinos em Mogi das Cruzes, Brasil, e Burj Al-Barajneh, Líbano (Prates, 2012), que contou com financiamentos do CNPq e da Faperj.

2 Quarenta e quatro anos, morava no bairro Dora, em Bagdá, no Iraque, e trabalhava para o governo iraquiano. Atualmente trabalha como degolador e supervisor no abate de carne halal em frigoríficos espalhados pelo Brasil - o que faz com que esteja a maior parte do tempo fora de Mogi das Cruzes, onde sua família reside.

3 Em 2007, 108 refugiados foram trazidos ao Brasil depois de permanecerem em um campo de refugiados na Jordânia por quase cinco anos, por consequência de sua fuga do Iraque após a invasão anglo-americana em 2003 - 56 deles acomodados em Mogi das Cruzes, e os outros 52 encaminhados para diferentes cidades do Rio Grande do Sul.
}

Horizontes Antropológicos, Porto Alegre, ano 20, n. 42, p. 133-152, jul./dez. 2014 
escorpião... a gente morava em tendas, no meio do deserto." Com o tempo, e à medida que meu relacionamento com o grupo foi se consolidando, e passei a fazer parte da rotina de algumas famílias, ${ }^{4}$ a lembrança do tempo vivido no campo parecia não querer abandoná-los. Em alguns momentos ela surgia, em meio a um almoço, ou entre as diversas conversas acompanhadas por um café. Um olhar perdido fixava-se no nada e as pessoas começavam a falar. Em uma dessas situações, eu estava almoçando com Fátima, ${ }^{5}$ conversando sobre a habilidade de seu caçula de comer quantidades desproporcionais para um garoto de 10 anos, quando, para minha surpresa, ela começou a falar:

Eu achava que ele ia morrer. Quando a gente foi pro campo ele era apenas um bebê, era recém-nascido. A barriga dele começou a ficar enorme e eu achava que ele tinha alguma doença. Levei para o médico analisar e disse que estava preocupada porque ele comia demais e estava com aquele barrigão. O médico deu risada de mim e disse que não estava acostumado a receber mães preocupadas porque o filho comia demais. Daí eu fiquei tranquila, mas não sei se ele é assim por causa do campo. Lá a comida era trazida e distribuída, a gente não escolhia nada, nem podia reclamar, tinha que se contentar com o que eles davam.

Em momentos como esse, passei a perguntar sobre como era a vida no campo, como eles haviam lidado com uma situação tão complexa como aquela. Foi quando me deparei com um esforço notadamente consciente de apagamento. Por várias vezes o relato era interrompido com frases do tipo: "não quero me lembrar disso", "o que passou, passou", "chega de falar em sofrimento". Esse seria um tema obrigatório, mas também ao mesmo tempo proibido, negado. A experiência no campo surgia como fragmentos desconexos na conversa: uma recordação da tentativa de horta, a lembrança das tempestades de areia, as brincadeiras improvisadas das crianças. Como flashes

4 Essa pesquisa etnográfica é baseada em 12 meses de pesquisa etnográfica realizada entre novembro de 2010 e novembro de 2011, dos quais oito meses foram dedicados à pesquisa em Mogi das Cruzes, interior de São Paulo, dois meses em Burj Al-Barajneh, no Líbano e dois meses em diversas cidades nos territórios ocupados da Palestina. Durante o período da pesquisa, morei durante todo o tempo com uma das famílias de refugiados, assim como meu período no Líbano se deu com seus familiares próximos.

5 Trinta e dois anos, formada em prótese dentária pela Universidade de Bagdá, morava no bairro Dora, em Bagdá. Sua família ocupava diferentes cargos militares no governo de Saddam Hussein. Trabalhou em laboratórios de prótese dental em Mogi das Cruzes, mas, por não conseguir o registro na Associação de Odontologia, teve de ser demitida. Atualmente cursa odontologia em uma universidade particular de Mogi das Cruzes.

Horizontes Antropológicos, Porto Alegre, ano 20, n. 42, p. 133-152, jul./dez. 2014 
de uma história não contada, ficava difícil tentar compreender como haviam sido aqueles quatro anos e meio. Optei por não forçar, decidi esperar e recolher os fragmentos para um dia, então, montar a imagem mais ampla desse período.

Somente no fim da minha pesquisa de campo, após mais de um ano de convivência e relacionamento, decidi perguntar de maneira mais direta sobre o tempo em Al-Ruweished, na Jordânia. Como seria de se esperar, a primeira reação foi uma atitude de esquivar-se, uma racionalização que optava por não lembrar. Em seguida, notando meu interesse, algumas histórias começavam a brotar.

Assim como o esquecimento, que parece fundamental no processo de construção de uma nova vida a partir de fragmentos recolhidos por uma história de deslocamentos, a rememoração também desempenha um papel central no processo de manutenção e estabelecimento de redes de relações a partir do compartilhar das experiências vividas. É nesse ponto que a memória será articulada na vida social dos refugiados de maneira a estabelecer vínculos tanto com a sociedade de acolhida como com os relacionamentos mantidos na dimensão global.

Para que se possa pensar a articulação da memória na vida social, é importante retomar a conceituação de Pierre Bourdieu (2006) acerca do relato biográfico como ilusão biográfica. Ele é basicamente uma "preocupação de dar sentido, de tornar razoável, de extrair uma lógica ao mesmo tempo retrospectiva e prospectiva" (Bourdieu, 2006, p. 184), ou seja, uma representação comum da existência que pretende dar sentido e direção a um conjunto de acontecimentos. Enfatizando a necessidade de se observar os mecanismos sociais que favorecem ou autorizam a experiência comum da vida como unidade e como totalidade, o autor aponta para a variabilidade do relato, tanto em forma como em conteúdo, de acordo com a qualidade social do mercado no qual é oferecido. Isso porque "os acontecimentos biográficos se definem como colocações e deslocamentos no espaço social, isto é, mais precisamente nos diferentes estados sucessivos da estrutura da distribuição das diferentes espécies de capital que estão em jogo no campo considerado" (Bourdieu, 2006, p. 190, grifo do autor). $\mathrm{O}$ que Bourdieu percebe é que não se pode compreender uma trajetória sem que se construam previamente os estados sucessivos do campo no qual ela se desenvolveu, bem como o conjunto das relações objetivas estabelecidas pelo agente junto ao conjunto dos demais agentes envolvidos no mesmo campo. O relato biográfico tem um fim social. 
Se o relato biográfico é constituído a partir da memória, tanto individual como coletiva, então é necessário que se pense nos diferentes pontos de referência que estruturam a memória, como afirmou Halbwachs (2006). Por ser toda lembrança uma reconstrução do passado com a ajuda de dados emprestados do presente, e de outras reconstruções feitas em diferentes épocas, a memória individual não está inteiramente isolada e fechada; da mesma maneira que a recusa de lembrar também está estruturada em diferentes pontos de referência que constrangem o agente. Lembrar é uma forma de se posicionar socialmente, o que também diz muito em relação ao esquecer.

Esses esquecimentos e silenciamentos foram mais bem explorados por Michael Pollak (1989) em seus estudos sobre os sobreviventes de campos de concentração nazistas - o que não significa dizer que a experiência do campo de concentração seja equivalente à experiência do campo de refugiados, mas de que a conceituação de Pollak pode ser produtiva para se pensar a relação entre a experiência em espaços temporários e excluídos socialmente com processos de reintegração e/ou adaptação pós-separação. Uma das questões levantadas pelo autor é a de que o silêncio sobre o passado está ligado à necessidade dos sobreviventes de encontrar um modus vivendi junto à sociedade - nesse caso, a sociedade que os deportou. O caso dos refugiados palestinos no Brasil é ainda diferente do pesquisado por Pollak, porque o que se vê aqui não é um retorno à sociedade que os expulsou; na realidade, o que se opera é uma adaptação a uma nova sociedade que nada tem a ver com os conflitos vivenciados no Iraque, ou mesmo na Palestina. Nesse caso, o silenciamento é também uma forma de encontrar um modus vivendi, uma forma de deixar a posição de vítima e retomar o controle de si. O silêncio seria, partindo dessa análise, não apenas uma forma de esquecer, mas uma forma de resistência contra a própria impotência dos indivíduos frente ao vivido; uma forma de retomar o controle sobre suas vidas, em um esforço consciente de apagamento. Como Pollak (1989, p. 11) aponta, “o que está em jogo na memória é também o sentido da identidade individual e do grupo"; o que retoma a proposição supracitada de Bourdieu sobre o relato biográfico como nada mais do que um esforço em dar sentido ao vivido, bem como uma direção. A lógica retrospectiva e prospectiva de que fala Bourdieu tem a ver com a própria identidade dos indivíduos, que está sendo construída a partir do relato. Como afirma Pollak (1989, p. 15), "mesmo no nível individual o trabalho da memória é indissociável da organização social da vida". 
Narrarei aqui três conversas que me parecem significativas para a compreensão do período no campo de refugiados: a primeira de Rania, ${ }^{6}$ uma senhora de 56 anos; a segunda de Tareq, ${ }^{7}$ um jovem de 27 anos; e a terceira a de Fadha,${ }^{8}$ uma senhora de 52 anos. É importante destacar que não pretendo apresentar uma categorização dos refugiados ${ }^{9}$ em geral, mas desenvolver questões que se apresentaram à medida que a pesquisa foi desenvolvida. Tendo em mente a crítica desenvolvida por Lisa Malkki (1995) sobre os riscos de se tentar definir um padrão da experiência dos refugiados, de maneira a construir estereótipos que reduzem o contexto histórico e social vivenciado por eles, a discussão que aqui se pretende diz respeito aos refugiados palestinos reassentados em Mogi das Cruzes, e ao processo pelo qual a memória é articulada no cotidiano dos sujeitos.

Passemos ao relato de Rania:

A vida no campo era muito difícil, como você sabe. Mas eu não consigo lembrar como a gente viveu lá por quase cinco anos. Parece engraçado dizer isso. Sabe, quando eu fui para o Líbano [ela acabara de retornar de uma viagem de três meses junto da família] minha irmã e minha mãe ficavam me perguntando: "Como foi que você aguentou tudo aquilo, como vocês viviam lá?", e eu disse pra elas: "Eu não sei, não lembro." Elas não acreditavam em mim e diziam: "Mas como você não lembra? Foram quase cinco anos Rania, você tem que lembrar!" Pois é, mas na verdade eu não sei como foi. Se você me perguntar como a gente viveu todo esse tempo, eu vou te dizer que foi como se o tempo parasse. Como se a gente fosse pra uma outra dimensão, onde nada acontecia. Era como se a gente não estivesse vivendo! [risos] Me lembrei agora de uma história engraçada. Um dia vieram umas pessoas do ACNUR [Agência da ONU para Refugiados]

6 Formada em letras e ciência política, morava no bairro Dora, em Bagdá. Atualmente trabalha como professora de língua francesa e árabe em Mogi das Cruzes.

7 Morava no bairro Medinat al-Huriya, em Bagdá, com sua mãe e irmãos, e apenas estudava. Hoje, trabalha como degolador no abate de carne halal em diversos frigoríficos espalhados pelo Brasil e sustenta o pai que mora em Mogi das Cruzes.

8 Iraquiana, casada com palestino. Morava no bairro Medinat al-Hurriya, em Bagdá, e trabalhava como esteticista. Atualmente está desempregada, mas têm procurado fazer cursos de estética no Senac de Mogi das Cruzes, pois pretende voltar a trabalhar.

9 Em minha dissertação realizo uma discussão mais aprofundada acerca da distinção entre imigração e deslocamento forçado, enfatizando o caráter dramático, traumatizante e violento dos deslocamentos forçados, bem como destacando a peculiaridade dos "refugiados reassentados", que estariam em uma nova situação de refúgio, ou seja, em um refúgio do refúgio.

Horizontes Antropológicos, Porto Alegre, ano 20, n. 42, p. 133-152, jul./dez. 2014 
pra conversar com as famílias, pra ver como nós estávamos, perguntar sobre nossas crianças. Várias mulheres estavam falando muito, reclamando e pedindo pra que alguma coisa fosse feita. Eu estava lá, sentada, calada. Iria falar o quê? Sabia que não resolveria nada. Daí uma das mulheres me perguntou: "Quantos anos o seu filho mais novo tem?" - ele estava passando por perto de nós. Eu respondi: "Treze." A mulher deu risada e me falou: "Rania, seu filho não tem 13 anos. Ele tinha 13 quando entrou aqui, isso foi há mais de dois anos atrás. Você está de brincadeira comigo!" Eu parei, pensei um pouco, e respondi: "Não, ele tem treze." A mulher me olhou como uma cara de "ela está louca", mas daí eu completei a frase: "Ele tem 13 anos porque essa foi a idade com que ele veio pra cá. O que ele viveu aqui não conta, porque isso aqui não é vida. Quando ele sair daqui eu volto a contar! Não quero que isso aqui faça parte da vida dele." E eu acho que é isso... por isso não me lembro. A gente não estava vivendo, era como se o tempo não passasse e a gente estivesse numa espera sem fim. Não podíamos sair. Nem escolher o que a gente ia comer a gente podia. Não éramos nada e não tínhamos o direito sobre nossa vida. O que eu posso te contar? Não tem o que contar! Eu sei que foi muito tempo, mas eu não estava vivendo lá, estava apenas sobrevivendo até poder sair.

Nesse dia conversamos por mais de cinco horas. Falamos da vida no Iraque, da vinda para o Brasil, da doença e consequente morte de seu marido já em Mogi das Cruzes no fim de 2010 - nós havíamos nos conhecido nas escadas do hospital onde seu marido estivera internado, na cidade. Houve momentos de emoção, nos quais ela desviou o olhar e buscou se recompor, momentos de risadas em que contou-me sobre seus filhos e como eles continuaram "bons meninos", momentos sérios quando me falou sobre a política e os abusos de poder no Oriente Médio. Mas durante todo o tempo de conversa, notei que a sensação de perder o controle sobre a própria vida era uma questão central que continuava a perturbá-la.

Rania definiu o período de permanência no campo de refugiados como um estado de suspensão, um período em que o tempo vai sendo paralisado, apenas retomado seu curso a partir da transferência para outro lugar. Um tempo in-between que ela não contava como vida, e em que a relação com a noção de temporalidade se mostra fundamental. Ao negar-se a contar os anos que o filho havia vivido no campo, Rania demonstra como esse período era percebido como não vida, como uma ausência do tempo - conceito que será melhor explorado nas páginas seguintes. Mais do que isso, a memória dos traumas vivenciados naquele momento faz com que o conteúdo 
não seja assimilado, embora relembrado pelas marcas no corpo. Ela me disse: "Quando fomos para o campo eles eram meninos... saíram de lá homens." Dessa forma, ainda que o conteúdo da memória do campo remeta a um estado de suspensão, como que não vivido, a própria alteração no corpo, como um suporte mnemônico ou auxiliar da memória (Pinto, 2002), faz com que os indivíduos percebam o avanço do tempo e sejam relembrados daquilo que se quer esquecido.

O outro relato é o de Tareq, que veio para o Brasil com seu pai, hoje com 67 anos. Ele fora para o campo jordaniano de Al-Ruweished com alguns amigos, o pai teria ido depois com a família do irmão mais velho. A família do irmão foi selecionada para reassentamento na Suécia, tendo permanecido no campo apenas ele e o pai.

O campo... ah, era difícil a vida lá. A gente morava no deserto, no meio do nada, cercado com cercas de arame farpado. Eu tinha fotos, mas rasguei tudo e joguei fora. Não quero lembrar daquele tempo. Chega! Eu fui pra lá na pior idade pra viver isso. Eu tinha 17 anos, e fiquei lá quase cinco anos. Saí de lá com 22 e agora estou com 27. Perdi a melhor fase da minha vida, os melhores anos. Quando saí de lá e entrei no avião eu decidi fechar a porta e deixar pra trás tudo o que passou. Decidi que iria esquecer, não quero lembrar. Quando eu fui pro campo eu era um garoto. Saí do Iraque porque estava muito perigoso, e tinha medo do que ia acontecer. Já fazia quase oito meses que a guerra tinha começado, estávamos sem energia há meses, sem água, e não podíamos andar nas ruas. Daí uns amigos meus disseram que estavam indo pra o campo e de lá a gente conseguiria ir pra outro país. Decidi ir com eles e tentar alguma coisa, porque ficar em Bagdá parecia impossível. Eu era muito novo, não sabia o que esperar. Quando a gente chegou lá, fomos pra uma barraca. Achei que ia ser por pouco tempo e que logo a gente ia pra outro país. Eu fui bobo. Minha família tentou conseguir um passaporte [falso] pra mim, eu só tinha que entrar no Iraque de novo, e na cidade perto da fronteira eles iam me entregar. Muita gente fez isso e seu deu bem, mas eu fiquei com medo, e logo recebi a "injeção" do ACNUR. Eles vinham de vez em quando e diziam que a situação iria se resolver dentro de alguns dias, pra gente não se desesperar. Era como uma injeção, era assim que a gente chamava quando percebemos que nada acontecia. Era uma injeção para acalmar a gente. Daí a gente foi vivendo. Não tinha o que fazer. O jeito era se acostumar. Não dava pra trabalhar, não dava pra fazer nada, só jogar carta e assistir televisão. Isso depois do primeiro ano, porque no começo ninguém saía das barracas, todo mundo estava em depressão. E... é isso, foi um tempo perdido da minha vida. Quero esquecer! 
Enquanto Tareq me contava sobre o tempo vivido no campo, seus olhos se enchiam de lágrimas repetidamente, e ele me dizia "me desculpa", como se eu esperasse qualquer outra reação que não a dor. O que fica claro a partir desses relatos, no entanto, é o esforço de apagamento da memória traumática, que não fala apenas da dificuldade de verbalizar a experiência, mas mais do que isso, é um esforço para esquecer e recomeçar uma nova vida sem aquela lembrança. Ao estabelecer o relato biográfico, os indivíduos buscam enquadrar a memória de maneira a estabelecer um modus vivendi, para que possam dar continuidade em suas vidas. O que implica, muitas vezes, uma decisão consciente de apagamento.

Passemos então ao relato de Fadha, uma senhora iraquiana casada com um palestino, mãe de duas adolescentes. Embora iraquiana, Fadha fugira com o marido e as filhas para o campo de Al-Ruweished por não querer se separar deles: "Não podia deixá-los. Como eu abandonaria minhas filhas?" Em uma de nossas últimas conversas, perguntei como tinha sido pra ela viver no campo por todo aquele tempo. Ela me olhou com uma expressão de "você não sabe?", levantando as mãos em um gesto de desdém irônico, que apontava para a obviedade da resposta.

O que eu posso te contar? Foi um tempo muito difícil, a gente morava em tendas, com colchões no chão, todo mundo junto em um espaço muito pequeno. Não tinha escola para as meninas. A gente ficava o dia todo sem ter o que fazer. Ficávamos lembrando das bombas que caíram em Bagdá, dos barulhos dos aviões de guerra. Deixei tudo pra trás, não podia voltar. A gente saiu porque meu marido era muito ligado ao Saddam. Você sabe, ele era cantor e sempre estava nas festas do partido cantando para o Saddam. Todo mundo sabia que ele recebia do governo. Quando a guerra começou, não tinha como continuar lá. Ele foi ameaçado de morte. O que fazer? A gente teve que fugir e ficamos presos no campo. Primeiro ficamos no meio do deserto, em outro campo, entre as fronteiras do Iraque e da Jordânia [na NML ${ }^{10}$. Esse campo era muito ruim, não tinha estrutura nenhuma, e a maioria das pessoas eram curdos. Depois de algum tempo conseguimos entrar no Ruweished, lá era melhor, já tinha uma certa estrutura pra gente viver. Mas era como se o tempo não passasse. Vivi cinco anos, mas parece que foram 50 anos! Eu envelheci lá. $\mathrm{O}$ dia demorava muito pra acabar. Não tinha o que fazer e nem pra onde ir. Não gosto de lembrar desse tempo.

${ }^{10}$ No man's land ("terra de ninguém”).

Horizontes Antropológicos, Porto Alegre, ano 20, n. 42, p. 133-152, jul./dez. 2014 
O que há de comum nesses três relatos é a dificuldade em verbalizar a experiência no campo, ainda que, para cada um, essa experiência seja traduzida de forma diferente. Enquanto para Rania é como se o tempo tivesse parado e ela simplesmente não conseguisse se lembrar, para Tareq é como se ele tivesse perdido os melhores anos de sua vida - e por isso o desejo de não se lembrar, o esforço de apagar. Já para Fadha é como se o tempo fosse suspenso e ampliado, como se ela tivesse vivido o equivalente a toda a sua vida, envelhecido em um lugar em que não podia viver - e por isso também a recusa em se lembrar. Estes são relatos que tratam da memória de maneira singular, são formas de lidar com uma memória traumática, de um tempo da vida que se quer esquecido.

Os relatos apontam para duas questões centrais: a relação com a memória e a temporalidade, e a relação com o espaço social - a perda de controle sobre a própria vida. Ambas questões se farão presentes no processo de integração na nova sociedade, e de busca por estabelecimento de um lugar social. Serão fundamentais na produção de uma metanarrativa que dê conta de acomodar os mais diversos acontecimentos guardados na memória, e capaz de viabilizar novos comportamentos na nova realidade.

No processo de elaboração de metanarrativas os sujeitos são constrangidos, tanto consciente como inconscientemente, a selecionarem o dito do não dito. No esforço de compreender as zonas de sombra, os silêncios e os "não ditos" das lembranças, Pollak retoma o trabalho de Claude Olievenstein acerca dos mecanismos psíquicos da emoção. Olievenstein (1988 apud Pollak, 1989, p. 8) afirma que

A linguagem é apenas a vigia da angústia... Mas a linguagem se condena a ser impotente porque organiza o distanciamento daquilo que não pode ser posto à distância. É aí que intervém, com todo poder, o discurso interior, o compromisso do não-dito entre aquilo que o sujeito se confessa a si mesmo e aquilo que ele pode transmitir ao exterior.

Desse modo, a impotência da linguagem é operacionalizada por meio do discurso interior que age como mediador entre o indivíduo e a sociedade. Selecionar o que deve ser dito faz parte de um recurso que Henry Rousso denomina "enquadramento da memória", e que tem relação com o que Bourdieu entende por "qualidade social do mercado". A referência ao passado não apenas mantém uma coesão de grupos e instituições, mas posiciona os indivíduos 
em relação à sociedade na qual estão inseridos. Por isso, selecionar o que deve ser dito diz muito a respeito do lugar a ser ocupado, pois o que é transmitido ao exterior será tomado como forma de representação desses agentes. Dessa maneira, a imagem que será apreendida a partir do que é dito faz parte do capital social dos refugiados ao se inserirem em uma nova sociedade.

Um outro aspecto do tratamento dado à memória diz respeito ao âmbito subjetivo. Se, no âmbito objetivo, o indivíduo provoca esses apagamentos como forma de organizar sua vida social, no âmbito subjetivo esses apagamentos fazem parte de uma complexa relação com sua cosmologia e o medo da dor. As violências vivenciadas levam a uma tentativa de compreensão do mundo, a questões de ordem existencial que confrontam seu já estabelecido quadro de referências cosmológicas. A velha questão do "por que isso aconteceu comigo?" vem à tona de maneira avassaladora. Nos primeiros contatos com os refugiados, notei um esforço constante de compreensão dos motivos que levaram ao sofrimento. Percebi que duas atitudes distintas se formavam, uma que questionava a ação divina e outra que afirmava seu cuidado. Em muitos relatos era latente a tentativa de não culpar a Deus pelo sofrimento vivido. Faziam questão de me dizer que Deus sabe de todas as coisas, que ele é bom e cuidou deles por todo o período que passaram no campo de refugiados após sua expulsão do Iraque, como nas palavras de Rania: "Alá cuidou de nós, a gente podia ter morrido no deserto. Foi ele quem nos trouxe para o Brasil pra começar uma nova vida!" Em outros, como nas palavras de Khalil, ${ }^{11}$ nota-se uma indignação em relação a Deus:

Por que isso aconteceu comigo? Me diz? Onde estava Deus quando tudo isso aconteceu? O que ele fez por mim? Ele estava dormindo! Não quero mais saber de Deus! Pra que eu vou falar com ele se ele não está me escutando? Ele está dormindo! Onde estava Deus quando eu fui parar no campo? Onde ele estava quando minha mãe morreu? Ele estava dormindo! [sua mãe viera de Gaza ao Brasil após solicitação de reintegração familiar, e depois de mais de 12 anos sem ver o filho. Três meses depois de sua chegada ao país, ela faleceria de pneumonia]

${ }_{11}$ Trinta e nove anos, nasceu em Gaza, na Palestina, e morou em diversos países do Oriente Médio em busca de trabalho. Após morar em Dubai foi para o Iraque, onde residiu no bairro Medinat al-Huriya, em Badgá.

Horizontes Antropológicos, Porto Alegre, ano 20, n. 42, p. 133-152, jul./dez. 2014 
O que nos leva a pensar no conflito vivenciado pelos refugiados ao tentarem dar sentido à sua experiência diante de um quadro de referências religiosas. O resultado pode aparecer como uma aproximação aos ensinamentos religiosos, numa tentativa de expiação dos pecados, ou então como um distanciamento da religião. $\mathrm{O}$ questionamento da existência ou não de Deus - e a consequente busca pela solução do problema da culpa - é, certamente, angustiante. É então que, retomando o pensamento de Olievenstein, pode-se perceber como tal angústia é vigiada pela linguagem, que, selecionada pelo discurso interior, decide o que é dizível e o que deve ser mantido oculto. Dessa forma, uma das maneiras de conviver com o trauma e com a tentativa de superação da consequente angústia representada pelo binarismo da existência ou da natureza de Deus, ou ainda com a racionalização da cosmologia, é o esquecimento. Deixar de pensar no que aconteceu pode apresentar-se como uma solução para que se deixe de pensar nos porquês de tais eventos.

Sobre esse aspecto, deve-se pensar ainda nos termos da conceituação de Allan Young (1997) sobre o medo da dor. Ao analisar o sofrimento e as origens da memória traumática, o autor retoma pesquisas realizadas no campo da memória filogenética, em que a dor passa a ter um papel significativo no conhecimento corpóreo, na medida em que ela nos ensina a temer eventos que causam ferimentos. $\mathrm{O}$ corpo aprende a temer a dor que acompanha o ferimento, e é precisamente porque a dor é indesejada que ela é também fundamental na preservação da espécie. É através do conhecimento da dor, e de sua inserção na memória filogenética, que a humanidade se preserva de sua própria destruição. Relembrando a afirmação de Charles Darwin segundo a qual "o medo é a memória da dor", Young (1997, p. 258) afirma que a memória é uma aflição através da qual a dor e o medo colonizam e degradam a vida-mundo do sofredor. Lembro-me vividamente do relato de Malak ao me confidenciar como teriam sido os primeiros anos no campo de refugiados. Malak é uma adolescente de 16 anos que chegou ao Brasil quando ainda tinha 13. Ela conta que quando foi para o campo de refugiados com os pais ainda muito pequena, tinha por volta dos 9 anos, teria passado noites sem conseguir dormir ao lembrar-se do som dos aviões que bombeavam Bagdá. "Foi muito difícil, eu era pequena e tinha muito medo, parecia que ainda ouvia o som dos aviões, dos bombardeios. Eu não conseguia dormir de medo. Depois que eu vim pro Brasil eu esqueci, agora é até difícil lembrar como era lá." 
Em se tratando de memórias traumáticas, que envolvem situações de violência, como é o caso da experiência vivenciada pelos refugiados palestinos procedentes do Iraque, a linguagem passa a ser aniquilada pela memória da dor, fazendo com que o vivido não possa mais ser trazido para o campo do dizível. Isso porque, nesse caso, a própria memória implica dor. Não lembrar é uma maneira de esquivar-se também da dor que a memória traz. Lembro-me de diversas vezes em que, ao questionar sobre a experiência de expulsão do Iraque e sobre o tempo vivido no campo de refugiados na fronteira jordaniana, ouvi repetidamente: "Não quero lembrar... muito sofrimento."

Por outro lado, a memória traumática é também fundamental para a preservação da comunidade simbólica, pois é ela que conecta as histórias de vida e reforça o sentimento de pertencimento. $\mathrm{O}$ trauma sofrido pelos palestinos acaba por reforçar a consciência de uma identidade palestina, como aponta Rashid Khalidi (2010), e é ainda um fator determinante na construção e reelaboração dela. A experiência catastrófica de 1948 e seu impacto em diferentes segmentos continua sendo um tópico recorrente entre os palestinos; independentemente da diversidade de experiências ou de gerações, a memória trágica é uma potente fonte de valores e crenças compartilhadas que corroboram para a reatualização da palestinidade. Haveria, portanto, uma relação fundamental entre a memória traumática e a construção da palestinidade, nas palavras de Khalidi (2010, p. 6), "a strong sense of palestinian national identity developed in spite of, and in some cases because of, the obstacles it faced". Isso faz com que o trauma e a violência sejam percebidos como motes privilegiados na memória palestina por sua capacidade de ancorar a experiência traumática, codificando e transmitindo sentidos por meio de processos cognitivos e associações políticas. Ainda que se perceba um esforço latente de esquecimento, é necessário lembrar para pertencer. Durante a pesquisa notei que era comum escutar histórias do campo, das famílias no Oriente Médio e em outros países ao redor do mundo nas frequentes visitas que algumas famílias mantêm entre si. ${ }^{12}$

Frente a isso, pode-se afirmar que o lugar do sofrimento é construído a partir de duas formas de produção de sentido, uma interna e outra externa

12 Essas visitas são realizadas por algumas poucas famílias, que, semanalmente, se dirigem às outras casas. Nem todos os refugiados mantêm contato direto entre si, o que me fez perceber que os laços de amizade mantidos no Brasil acabam por reproduzir os laços desenvolvidos no campo de refugiados; ou, ainda, laços já estabelecidos no Iraque - como é o caso de duas famílias. 
- que apontam para as dimensões subjetiva e objetiva da experiência no mundo. E é exatamente essa necessidade de produção de sentido que implicará uma atitude em relação à memória que diz respeito ao esforço em dar uma direção à vida - o que configura a característica prospectiva de que falava Bourdieu. Ao serem inseridos em uma nova sociedade, os refugiados precisam lidar com a memória, decidir o enquadramento necessário para recomeçar, os apagamentos necessários, da mesma forma que precisam lidar com a rememoração que os conecta a uma comunidade simbólica.

Parece ser necessário estabelecer, neste ponto, uma distinção entre memória do trauma e memória traumática, uma vez que a memória do trauma é aquela relacionada à memória filogenética, que representa o medo da dor que o trauma produziu e que é inserido na memória coletiva; embora seja carregada de sentimentos e esforços de silenciamento pela dor que a própria memória infringe, é importante para o estabelecimento de vínculos sociais. Enquanto que a memória traumática vai além do medo da dor, na medida em que o simples ato de lembrar causa dor, por isso a necessidade de apagamento. Ela é vivida individualmente, mantida no campo do indizível, pois de outra forma traria sofrimento. Se, por um lado, a memória do trauma é fundamental na preservação da espécie, na medida em que insere nos indivíduos o medo de vivenciar novamente o sofrimento, e é fundamental na elaboração e reelaboração de comunidades simbólicas, uma vez que está relacionada à identificação e ao compartilhamento de experiências de vida, por outro, a memória traumática é aquela que retoma o sofrimento e, por isso, parece ser fundamental tentar apagá-la ou silenciá-la para a própria reconstrução da subjetividade dos indivíduos; não lembrar é, assim, não sofrer novamente.

Essa distinção pode ser aprofundada por meio da conceituação estabelecida pelo antropólogo Harvey Whitehouse (2000), em que é possível perceber processos diferenciados de codificação e transmissão da memória. $\mathrm{O}$ autor aponta para a importância da memória e, consequentemente, das teorias da psicologia cognitiva para a construção de teorias antropológicas.

Whitehouse elaborou um modelo teórico para pensar os modos de religiosidade, definidos por ele através do par doutrinal e imagístico. Seu ponto de partida para a teorização desses modos advém de uma conceituação da psicologia cognitiva, que apresenta uma dicotomia entre a memória semântica e a memória episódica. A primeira refere-se a representações mentais de generalizações estabelecidas a partir de ações de reforço e repetição das experiências 
comuns, classificando e modalizando em esquemas ${ }^{13}$ as experiências recorrentes. A segunda refere-se a representações mentais de eventos experienciados exclusivamente, tornando-se episódios únicos para os indivíduos e que, em contraste com a memória semântica, resultam em novos repertórios, novos esquemas. Dessa forma, a memória semântica funcionaria como um denominador comum de uma série de memórias episódicas - e decorrente de um processo de abstração e generalização.

A principal diferenciação entre o modo doutrinal e o modo imagístico de religiosidade estaria precisamente nos diferentes processos de codificação e transmissão do conhecimento religioso operados pela memória semântica e pela memória episódica. No modo doutrinal, a codificação e transmissão está diretamente ligada à rotinização e frequente repetição do ritual e do dogma, que pretendem uma certa coerência interna. $\mathrm{O}$ autor aponta para a descontextualização operada no modo doutrinal, em que aspectos particulares ou individuais são deixados de lado a despeito de uma concepção de comunidade, o que corresponde aos esquemas codificados pela memória semântica. Já no modo imagístico, a codificação e transmissão se dão pela memória episódica, e estão relacionadas a episódios de ritos traumáticos e violentos, como os rituais de iniciação, que são, portanto, particulares. Esses episódios, dada a sua exclusividade, estabeleceriam novos esquemas que incorporariam a variedade dos elementos contidos na experiência, mantendo-os vividamente detalhados na memória. A longevidade e intensidade dessas memórias corresponderiam à capacidade de coesão e manutenção dentro de um grupo muito restrito. No entanto, esses modos de religiosidade não seriam excludentes, podendo se sobrepor ou justapor.

Fredrik Barth (2002) traz uma importante crítica à análise de Whitehouse ao questionar a abordagem do autor em relação ao modo imagístico, em que faz do mecanismo de função da memória sua chave de leitura. A questão proposta por Barth é a de como a memória pode estabelecer e transportar as imagens e o conhecimento que são transmitidos nas longas e sequenciais séries de eventos de uma iniciação; e, além disso, que conteúdo da memória do ritual iniciatório experienciado será assimilado e relembrado. Valendo-se de seu material etnográfico, Barth aponta para o caráter traumático do ritual, que faz

${ }^{13}$ Os esquemas seriam as estruturas mentais que fixam uma sequência aos episódios que se repetem. 
com que o noviço não assimile e não recorde grande parte do conteúdo de sua experiência iniciatória. Para Barth, os rituais apresentam os dois processos cognitivos de codificação e transmissão realizados pelas memórias semântica e episódica, de maneira que os dois modos de memória funcionem com propósitos complementares.

Outra importante contribuição para pensarmos o modelo teórico de Whitehouse, e que avança a discussão iniciada por Barth, é a análise de Paulo Pinto (2002) sobre os rituais sufis. Ao criticar o excesso de ênfase dada aos mecanismos psicológicos para a explicação dos modos de religiosidade e das formas de ação do ritual, como também a suposição de Whitehouse de que eventos esporádicos e extraordinários teriam um efeito e durabilidade similar na consciência dos diferentes participantes do ritual, o autor aponta para a criação de uma memória dupla: uma visual na audiência, e outra personificada no agente. Segundo Pinto (2002, p. 252), essas memórias não seriam incontroladas, mas constantemente reforçadas por elementos materiais, o que ele chama de "auxílios da memória", como as cicatrizes no corpo, a presença dos instrumentos de flagelação nos rituais e a repetição desses mesmos rituais. Esses "auxílios da memória" controlam ou canalizam os elementos que serão retidos em cada uma das experiências, reforçando sua durabilidade na memória de cada um dos participantes. Retomando a análise de Pierre Clastres sobre como as cicatrizes podem ser usadas como um dispositivo mnemônico, em que o autor afirma que "o corpo é uma memória", Pinto (2002) incorpora para a análise de Whitehouse um novo elemento, o corpo e sua função na memória episódica.

Tomando a discussão proposta por Barth e Pinto, podemos avançar no modelo teórico de Whitehouse acerca da memória episódica, que agora precisa ser pensada não mais como uma lembrança vívida e particular de cada detalhe do evento e nem como experiência compartilhada de igual forma pelos participantes, recordada por sua exclusividade, mas como experiência traumática, que impede a assimilação e recordação dos detalhes e que será rememorada a partir de auxiliares materiais, o que, por fim, delimitará posteriores experiências que reforçarão a memória episódica. Essa discussão é fundamental para que se pense o trauma e a violência como experiências que servem como âncoras existenciais, que serão codificadas e transmitidas pela memória, e farão parte do quadro de referências dos agentes, delimitando comportamentos futuros. Assim como os modos de religiosidade, trauma e violência são 
experiências sociais que codificam e transmitem para os indivíduos associações a serem estabelecidas, como também uma relação particular com a noção de temporalidade.

Cada uma das memórias propostas por Whitehouse pode ser explorada de acordo com uma noção de dinâmica seletiva mnemônica que é própria dos processos de codificação e transmissão. Por dinâmica seletiva mnemônica me refiro ao caráter silenciador da memória e pode ser compreendido a partir de uma metáfora do compasso musical. O compasso aponta para a marcação do tempo, para uma ideia de linearidade, ao mesmo tempo em que pressupõe em sua própria estrutura a existência de um contratempo, uma ausência da marcação que acaba por ser fundamental na constituição de sua própria função linear. Vista dessa maneira, a memória semântica pode ser comparada ao tempo musical, marcado e repetido, normalizando a temporalidade, enquanto que a memória episódica aproxima-se do contratempo musical, ausente e marcador da suspenção dos espaços, rompendo com a temporalidade no mesmo instante em que lhe fornece novos elementos.

Propôs-se aqui essa metáfora para uma melhor compreensão sobre como os processos de codificação e transmissão da memória desenvolvem-se por meio de uma dinâmica seletiva mnemônica e que implicará em modos de comportamento específicos. Se, por um lado, a memória semântica se estabelece a partir da repetição, uma narrativa linear será desenvolvida, propondo uma normatização dos eventos, o que implicará a construção de metanarrativas que estabelecem uma ordem e coerência aos acontecimentos. Por outro lado, a memória episódica é estabelecida pela peculiaridade do momento, que produz uma ruptura na narrativa, deixando marcas materiais que implicam a retomada da experiência e remetem a um estado de suspensão, de quebra da normalidade.

Em relação aos refugiados palestinos, pode-se perceber de que maneira memória semântica e memória episódica serão acionadas à medida que os agentes procuram lidar com sua experiência de vida. A memória semântica será responsável por dar coerência à trajetória de vida, explicando de maneira inteligível o percurso de deslocamentos compartilhados pelos refugiados palestinos em um espectro ampliado, e que retoma uma explicação causal ligada à expropriação territorial em 1948, e que acaba por caracterizar a experiência palestina em geral, ao mesmo tempo em que produz uma narrativa pessoal de deslocamento - o que remete à argumentação de Bourdieu, em que 
uma ideia de trajetória é desenvolvida. A memória semântica seria então responsável por gerenciar e dar sentido às experiências vividas, fornecendo aos indivíduos uma perspectiva de temporalidade que se quer linear - e que pode ser relacionada com a memória do trauma, que os conecta a uma comunidade simbólica. Por outro lado, a memória episódica será responsável por definir e relembrar aos indivíduos as experiências violentas vivenciadas nos momentos de conflito, como a fuga do Iraque e o tempo no campo de refugiados; reforçada pelos "auxílios da memória" que são as marcas no corpo, produzirá uma noção de tempo em suspensão, uma vez que, assim como nos rituais, em sua experiência o tempo linear também é rompido - o que pode ser definido como a memória traumática, que retoma a experiência da dor.

Embora diferentemente dos rituais religiosos descritos por Fredrik Barth (2002) ou Paulo Pinto (2002), nos quais a memória traumática é reforçada pela repetição do ritual, o trauma vivenciado pelos refugiados não será necessariamente repetido, embora encontre eco na narrativa palestina mais geral e em sua história de constante deslocamento. No entanto, assim como no processo ritual descrito por Pinto, o corpo será um repositório de auxiliares da memória, que reforçam a rememoração da experiência. Durante minha pesquisa etnográfica, notei que marcas no corpo funcionavam como âncoras para o acionamento da memória. Sempre que começavam espontaneamente a descrever o tempo vivido no campo de refugiados, falavam a partir de um problema de saúde que se havia desenvolvido lá, ou do envelhecimento do corpo, ou ainda das rugas na pele, das marcas deixadas pelo sol ou da aparência cansada.

Fadha certa vez me disse: "Eu envelheci naquele lugar, olha a minha pele, não era assim quando eu morava no Iraque. Eu era esteticista, minha pele era linda, mas depois do campo nunca mais voltou ao normal." Em outra circunstância conversava com Fátima sobre sua visita ao médico, quando ela começou a me descrever todos os seus problemas de saúde atuais: "Estou com problema no coração, com hipertireoidismo, com asma e tive que retirar o útero. Tudo isso começou no campo. A vida era muito difícil, o clima, as condições eram péssimas." Em outra conversa com Tareq, ele apontou para os anos perdidos: "Entrei no campo menino, um adolescente cheio de sonhos, saí de lá homem." Aos poucos notei que o corpo era para os refugiados esse elemento material de que fala Pinto (2002), um auxílio da memória que canalizava as recordações que se queriam apagadas. 
É então que memória do trauma e memória traumática se justapõem, ou se complementam. A memória do trauma produz uma narrativa que permite que os indivíduos normalizem as experiências de vida, colocando-as de maneira linear dentro de uma temporalidade progressiva. Os diversos deslocamentos vivenciados pelos refugiados palestinos acabam por ser integrados como marcações no tempo vivido, enquanto que os traumas e violências vivenciados no Iraque e no campo de refugiados são quase que silenciados nesse processo, são rememorados a partir da memória traumática, que se vale do próprio corpo dos indivíduos, mas que são narrados como um tempo em suspensão, definidos como um período de negação: "Eu não me lembro... eu não quero lembrar."

\section{Referências}

BARTH, F. Book review of Arguments and Icons: Divergent Modes of Religiosity (Harvey Whitehouse, Oxford Univ. Press, 2000). Journal of Ritual Studies, v. 16, n. 2, p. 14-17, 2002.

BOURDIEU, P. A ilusão biográfica. In: AMADO, J.; FERREIRA, M. (Org.). Usos e abusos da história oral. Rio de Janeiro: FGV Editora, 2006. p. 183191.

HALBWACHS, M. A memória coletiva. São Paulo: Centauro, 2006.

KHALIDI, R. Palestinian Identity: the construction of modern national consciousness. New York: Columbia University Press, 2010.

MALKKI, L. Purityand exile: violence, memory, and national cosmology among Hutu refugees in Tanzania. Chicago: The University of Chicago Press, 1995.

PINTO, P. Mystical bodies: ritual, experience and the embodiment of sufism in Syria. Thesis (Ph.D.)-Boston University, Boston, 2002.

POLLAK, M. Memória, esquecimento e silêncio. Estudos Históricos, Rio de Janeiro, v. 2, n. 3, p. 3-15, 1989. 
PRATES, D. R. A. O fio de Ariadne: deslocamento, heterotopia e memória entre os refugiados palestinos em Mogi das Cruzes, Brasil, e Burj Al-Barajneh, Líbano. Dissertação (Mestrado em Antropologia)-Instituto de ciências Humanas e Filosofia, Universidade Federal Fluminense, Rio de Janeiro, 2012.

YOUNG, A. Suffering and the origins of traumatic memory. In: KLEINMAN, A.; DAS, V.; LOCK, M. Social suffering. Berkeleyn: University of California Press, 1997. p. 245-260.

WHITEHOUSE, H. Arguments and icons: divergent modes of religiosity. Oxford: Oxford University Press, 2000.

Recebido em: 31/12/2013

Aprovado em: 09/06/2014 